\title{
Correction to: Opportunities and limits of combining microbiome and genome data for complex trait prediction
}

Miguel Pérez-Enciso ${ }^{1,2,4^{*}} \mathbb{0}$, Laura M. Zingaretti ${ }^{2,4}$, Yuliaxis Ramayo-Caldas ${ }^{3}$ and Gustavo de los Campos ${ }^{4}$

\section{Correction to: Genet Sel Evol (2021) 53:65 https://doi.org/10.1186/s12711-021-00658- 7}

Following publication of the original article [1], the authors noticed the following two errors:

(1) Figures 1 and 2 are swapped, but the legends and figure numbers are correct, that is, the legend indicated for Figure 1 is in the right place but corresponds to Figure 2, and vice versa;

and

(2) In the Funding section, the statement:

MPE is funded by Ministry of Science and Innovation-State Research Agency (AEI) Grant PID2019-108829RB-I00 is incomplete. The correct paragraph should be:

MPE is funded by the Ministry of Science and InnovationState Research Agency (MICIN/AEI/10.13039/501100 011033) Grant PID2019-108829RB-I00.

\begin{abstract}
Author details
${ }^{1}$ ICREA, Passeig de Lluís Companys 23, 08010 Barcelona, Spain. ${ }^{2}$ Centre for Research in Agricultural Genomics (CRAG), CSIC-IRTA-UAB-UB, 08193 Bellaterra, Barcelona, Spain. ${ }^{3}$ Animal Breeding and Genetics Program, Institute for Research and Technology in Food and Agriculture (IRTA), Torre Marimon, 08140 Caldes de Montbui, Barcelona, Spain. ${ }^{4}$ Dept. of Epidemiology \& Biostatistics, and Dept. of Statistics \& Probability, Michigan State University, East Lansing, MI 48824, USA.
\end{abstract}

Published online: 20 December 2021

\section{Reference}

1. Pérez-Enciso M, Zingaretti LM, Ramayo-Caldas Y, de los Campos G. Opportunities and limits of combining microbiome and genome data for complex trait prediction. Genet Sel Evol. 2021;53:65. https://doi.org/10. 1186/s12711-021-00658-7

\section{Publisher's Note}

Springer Nature remains neutral with regard to jurisdictional claims in published maps and institutional affiliations. original author(s) and the source, provide a link to the Creative Commons licence, and indicate if changes were made. The images or other third party material in this article are included in the article's Creative Commons licence, unless indicated otherwise in a credit line to the material. If material is not included in the article's Creative Commons licence and your intended use is not permitted by statutory regulation or exceeds the permitted use, you will need to obtain permission directly from the copyright holder. To view a copy of this licence, visit http://creativecommons.org/licenses/by/4.0/. The Creative Commons Public Domain Dedication waiver (http://creativeco mmons.org/publicdomain/zero/1.0/) applies to the data made available in this article, unless otherwise stated in a credit line to the data. 